Article

\title{
Inhibition of Cyclic Adenosine Monophosphate- Specific Phosphodiesterase by Various Food Plant-Derived Phytotherapeutic Agents
}

\author{
Teresa Röhrig (D), Olga Pacjuk, Silvia Hernández-Huguet, Johanna Körner, Katharina Scherer \\ and Elke Richling * \\ Division of Food Chemistry and Toxicology, University of Kaiserslautern, Erwin-Schroedinger-Straße 52, \\ 67663 Kaiserslautern, Germany; roehrig@chemie.uni-kl.de (T.R.); olga_pacjuk_@freenet.de (O.P.); \\ siviahh_20_bcn@hotmail.com (S.H.-H.); johanna-koerner@gmx.de (J.K.); katha-scherer@gmx.de (K.S.) \\ * Correspondence: richling@chemie.uni-kl.de; Tel.: +49-631-205-4061
}

Received: 23 August 2017; Accepted: 1 November 2017; Published: 4 November 2017

\begin{abstract}
Background: Phosphodiesterases (PDEs) play a major role in the regulation of cyclic adenosine monophosphate (cAMP)- and cyclic guanosine monophosphate (cGMP)-mediated pathways. Their inhibitors exhibit anti-inflammatory, vasodilatory and antithrombotic effects. Therefore, consumption of foods with PDE-inhibiting potential may possess beneficial influence on the risk of cardiovascular diseases. Methods: Four plant extracts (Arbutus unedo, Camellia sinensis, Cynara scolymus, Zingiber officinale) with promising ingredient profiles and physiological effects were tested for their ability to inhibit cAMP-specific PDE in vitro in a radioactive assay. Results: Strawberry tree fruit (Arbutus unedo) and tea (Camellia sinensis) extracts did not inhibit PDE markedly. Alternatively, artichoke (Cynara scolymus) extract had a significant inhibitory influence on PDE activity $\left(\mathrm{IC}_{50}=0.9 \pm 0.1 \mathrm{mg} / \mathrm{mL}\right)$ as well as its flavone luteolin $\left(\mathrm{IC}_{50}=41 \pm 10 \mu \mathrm{M}\right)$ and 3,4-dicaffeoylquinic acid $\left(\mathrm{IC}_{50}>1.0 \mathrm{mM}\right.$ ). Additionally, the ginger (Zingiber officinale) extract and one of its constituents, [6]-gingerol, significantly inhibited $\mathrm{PDE}$ ( $\mathrm{IC}_{50}=1.7 \pm 0.2 \mathrm{mg} / \mathrm{mL}$ and $\mathrm{IC}_{50}>1.7 \mathrm{mM}$, respectively). Crude fractionation of ginger extract showed that substances responsible for PDE inhibition were in the lipoid fraction $\left(\mathrm{IC}_{50}=455 \pm 19 \mu \mathrm{g} / \mathrm{mL}\right)$. Conclusions: A PDE-inhibitory effect was shown for artichoke and ginger extract. Whether PDE inhibition in vivo can be achieved through ingestion of artichoke or ginger extracts leading to physiological effects concerning cardiovascular health should be addressed in future research.
\end{abstract}

Keywords: Arbutus unedo; Camellia sinensis; Cynara scolymus; Zingiber officinale; phosphodiesterase; cyclic AMP

\section{Introduction}

Phosphodiesterases (PDEs) hydrolyze phosphodiester bonds in the second messengers $3^{\prime}, 5^{\prime}$-cyclic adenosine monophosphate (cAMP) and $3^{\prime}, 5^{\prime}$-cyclic guanosine monophosphate (cGMP), resulting in the nucleoside $5^{\prime}$-monophosphates AMP and GMP, respectively. Along with adenylate and guanylate cyclases, PDEs play a major role in regulating cAMP- and cGMP-mediated signaling. Thus far, 11 PDE families, differing in substrate specificity and inhibitor selectivity, have been identified. Molecules that can selectively inhibit PDEs are attractive for pharmaceutical research because the inhibition of PDEs results in various physiological effects [1,2]. To demonstrate, PDE V inhibitors are used to treat hypertension because cGMP activates nitric oxide-mediated vasodilation [3]. Furthermore, PDE III and $\mathrm{V}$ inhibitors show significant antithrombotic effects through the inhibition of thrombin-mediated platelet activation [2]. Moreover, the nonspecific PDE inhibitor theophylline has anti-inflammatory properties and is used as additional therapy for patients with asthma or chronic obstructive pulmonary 
disease (COPD) [4]. These add-on therapy approaches can also use specific inhibitors, such as the newly licensed PDE IV inhibitor roflumilast, which is used to treat COPD [5]. However, certain compounds originating from foods can inhibit PDE. Caffeine and other methylxanthines, for example, had already been recognized as nonspecific inhibitors at the time of phosphodiesterase discovery [6,7]. Coffee has been shown to have both in-vitro and in-vivo PDE-inhibiting effects [8-10]. Furthermore, some classes of flavonoids (flavonols, flavones, anthocyanins and anthocyanidins, flavanones, and flavanonols) have shown PDE-inhibiting potential, whereas catechins are not potent PDE inhibitors [11-15]. Foods containing flavonoids have also demonstrated potent PDE inhibition, as shown by the in-vitro inhibition of cGMP-specific PDEs by red grape extract [16]. These results have led to a hypothesis that food compounds with PDE-inhibitory properties could lead to a PDE inhibition in vivo resulting in physiological effects with beneficial impact on health. Furthermore, certain plants that are traditionally used in phytotherapy to prevent, and treat, ischemic and inflammatory diseases, are also consumed as food. However, for most of these foods only parts of the mechanism of action are known and the efficacy of these compounds is still under discussion. To connect PDE inhibition with their physiological effects, we tested the PDE inhibitory potential of four promising food plant extracts: strawberry tree (Arbutus unedo L., Ericaceae) fruit extract (SFE), green tea (Camellia sinensis L., Theaceae) leaf extract (TXE), artichoke (Cynara scolymus L., Asteraceae) leaf extract (ALE) and ginger (Zingiber officinale Roscoe, Zingiberaceae) rhizome extract (GPE).

Arbutus unedo is used as an alternative treatment for hypertension and diabetes in Morocco [17]. It has antihypertensive effects, which have been attributed to a nitric oxide-dependent mechanism that is still not completely understood [18,19]. Furthermore, extracts from Arbutus unedo leaves have been shown to have anti-aggregative effects, as they significantly reduce in-vitro thrombin-induced platelet aggregation in a concentration-dependent manner [20,21]. These effects suggest PDE inhibition as a possible mechanism of action. The edible berries are used to produce jams, liqueurs and beverages, but these are only distributed regionally throughout the Mediterranean countries. The fruits are rich in gallic acid derivatives, proanthocyanidins, catechins and anthocyanins [22-24]. The fresh fruit contains anthocyanins at concentrations between 0.5 and $9.7 \mathrm{mg}$ per $100 \mathrm{~g}$, with cyanidin-3-O-galactoside as the most abundant anthocyanin present [22-24]. The well-known hydroquinone derivative arbutin (hydroquinone $\beta$-D-glucopyranoside) can also be extracted from both the leaves and fruits of Arbutus unedo [23,25]. The fruits also contain small amounts of flavonols and ellagic acid derivatives [22].

Camellia sinensis leaves are the base for different kinds of teas, which are classified by fermentation stage. Green, unfermented tea has the highest flavonoid content among different tea types, especially in terms of catechins, ranging from approximately $8 \%$ to $30 \%$ of dry matter. Teas contain various catechins, such as (-)-epigallocatechin gallate (EGCG), (-)-epicatechin gallate (ECG), (-)-epigallocatechin (EGC), (-)-epicatechin (EC), (-)-gallocatechin gallate (GCG), (-)-gallocatechin (GC) and (+)-catechin (C), with EGCG being the most abundant [26-32]. The caffeine content of green tea leaves normally averages between $2 \%$ and $4 \%$ of dry matter $[26,28,31,33]$, but values up to almost $8 \%$ have been reported, with theobromine $(<0.6 \%)$ and theophylline $(<0.06 \%)$ appearing in insignificant amounts [30]. Green tea can have various physiological effects through antioxidant, anti-inflammatory and antithrombotic properties, and its consumption has been suggested to decrease the risk of degenerative diseases, especially cardiovascular disease [34,35]. The antithrombotic effect of green tea results from catechin-mediated inhibition of platelet activation. The mechanism of this antiplatelet activity is still not fully understood, but is correlated with increased intracellular cAMP levels [36-38]. Together with the ingredient profile, these physiological effects point to PDE inhibition as a possible mechanism of action.

The flower buds, prior to blooming, of Cynara scolymus (artichoke), are relevant for culinary purposes, while the leaves are processed for phytotherapeutic applications. Extracts from artichoke leaves are used in the prevention of arteriosclerosis due to cholesterol-lowering [39,40] and antihypertensive effects [41]. The antihypertensive effect results from an upregulation of endothelial-type nitric oxide synthase genes [41]. Furthermore, artichokes have antioxidant properties as they are rich in phenolic compounds, such as chlorogenic acids and flavones [42,43]. Chlorogenic 
acids can be found in artichoke heads at levels reaching $9.4 \mathrm{~g} / \mathrm{kg}$ dry matter, with 5-caffeoylquinic acid and 1,5-dicaffeoylquinic acid the most prominent mono- and dicaffeoylquinic acids, respectively. 1,3-dicaffeoylquinic acid (cynarin) can also be found in artichokes in smaller amounts, and is mostly formed through heat-induced isomerization. The most prominent flavones include luteolin (concentrations reaching $0.7 \mathrm{~g} / \mathrm{kg}$ dry matter) and apigenin (concentrations reaching $5.4 \mathrm{~g} / \mathrm{kg}$ dry matter), which are mainly present as glucuronides, but exist also as glucosides and rutinosides. To contrast, the amounts of the flavanones naringenin 7-O-glucoside and narirutin in artichokes are insignificant, and aglycones are only found in trace amounts [44-46]. Phenolic compound concentrations are even higher in artichoke leaves than in the globe heads [47]. Furthermore, sesquiterpene lactones, specifically guaianolides, have been identified in Cynara scolymus [48]. Rich in flavonoids, artichokes may possess PDE-inhibiting potential.

Ginger (Zingiber officinale Roscoe), especially the rhizome, is commonly used in phytotherapy and has a long history in traditional Chinese medicine (TCM). Furthermore, it is a key ingredient of Asian cuisine. Its use in European cuisine is also on a steady rise. The net import of ginger and ginger products into Europe in 2012 was estimated at 59,000 tons, around 35,000 tons more than in 2002 (FAOSTAT). The constituents responsible for ginger's pungent taste and rich aroma are found in non-volatile and volatile fractions of rhizome oleoresin. The non-volatile fraction contains a group of pungent compounds that contain a phenolic ketone moiety. These phenolic compounds include gingerols and their degradation products: shogaols, gingerdiols, gingerdiones, dehydrogingerdiones, diacetoxy gingerdiols, acetoxy gingerols, acetoxy gingerdiols and paradols [49]. The most abundant phenolic compound in fresh rhizome is [6]-gingerol, with concentrations ranging between 120-2100 $\mu \mathrm{g} / \mathrm{g}$ [50]. The physiological effects, and therefore applications, of ginger in phytotherapy are numerous, ranging from anti-emetic and antidiabetic therapy (serotonin antagonism) [51-55] to analgesic, anti-inflammatory and antithrombotic effects (cyclooxygenase inhibition) [56]. Furthermore, the phenolic compounds found in ginger, especially dehydrogingerdiones, are potent antioxidants [57-59]. The abundancy of secondary plant metabolites and the multiple physiological effects of ginger indicate PDE inhibition as a possible mechanism of action.

These four food plants may contain potent PDE inhibitors explaining their physiological effects. To investigate this, extracts of these four food plants were tested for their inhibiting potential on cAMP-specific PDE in vitro, with the aim to then identify the compounds responsible for PDE inhibition and quantify their effectiveness as inhibitors. Arbutus unedo, Camellia sinensis and Cynara scolymus have not been tested for PDE inhibitory potential before. However, several studies have researched the PDE inhibitory potential of Zingiber officinale, but the results are inconsistent [60-63].

\section{Materials and Methods}

\subsection{Chemicals, Cell Lines and Reagents}

All the chemicals and reagents used were purchased in analytical quality. The purity of reference substances was $>95 \%$. 3,4-dicaffeoylquinic acid (3,4-DiCQA) was available from earlier studies [64]. The AMP, arbutin, benzamidine, bovine serum albumin (BSA), caffeine, cAMP, formic acid, [6]-gingerol, luteolin-7-O-glucuronide, 3,4,5-trimethoxycinnamic acid and XAD16N materials were purchased from Sigma Aldrich (Taufkirchen, Germany); apigenin, luteolin and luteolin-7-O-glucoside from Extrasynthese (Genay Cedex, France); leupeptin, pepstatin A and phenylmethylsulfonyl fluoride from Alexis Biochemicals (Loerrach, Germany); rolipram from Calbiochem (La Jolla, CA, USA); and $\left[2,8-{ }^{3} \mathrm{H}\right]-3^{\prime} 5^{\prime}$-cyclic adenosine monophosphate ammonium salt, 9.25 MBq/mL, from Hartmann Analytic (Braunschweig, Germany). The LXFL529L cell line was kindly provided by Prof. Fiebig (Freiburg, Germany).

\subsection{Strawberry Tree Fruit Extraction}

Arbutus unedo L., Ericaceae, fruits were collected in the Najac region of Languedoc, Southern France during October 2014. A sample of $91 \mathrm{~g}$ of fruit was homogenized and extracted with $\mathrm{H}_{2} \mathrm{O} /$ methanol/ 
formic acid 38/60/2 (v/v/v) for $4 \mathrm{~h}$. Briefly after paper filtration (MN 615, Macherey Nagel, Düren, Germany) and partial concentration, the crude extract was purified with an XAD16N-packed column $(50 \mathrm{~mL})$. The column had been equilibrated with $500 \mathrm{~mL} \mathrm{2 \%}$ formic acid, and after applying $33 \mathrm{~mL}$ of the crude extract the column was washed with $300 \mathrm{~mL} 2 \%$ formic acid. Elution was carried out with $300 \mathrm{~mL} \mathrm{90 \%} \mathrm{ethanol.} \mathrm{The} \mathrm{eluate} \mathrm{was} \mathrm{dried} \mathrm{in} \mathrm{a} \mathrm{vacuum} \mathrm{and} \mathrm{the} \mathrm{residue} \mathrm{was} \mathrm{freeze-dried} \mathrm{and}$ homogenized. The yield of strawberry tree fruit extract (SFE) from the sample was $0.8 \%$.

\subsection{Quantification of Arbutin in SFE}

Arbutin quantification in SFE was performed according to [65], with slight modifications, on an Agilent 1200 series HPLC system (Model G1312B) (Agilent Technologies, Santa Clara, CA, USA) equipped with a degasser (G1379B), binary pump (G1312B), auto-sampler (G1317C), column oven (G1316B) and DAD detector (G1315). The HPLC conditions: column Luna $5 \mu \mathrm{m} \mathrm{C18} 100 \AA$, $250 \times 4.6 \mathrm{~mm}$ (Phenomenex, Torrance, CA, USA); solvent system: A-0.04\% formic acid, B-methanol; gradient profile: isocratic $2 \%$ B for $3 \mathrm{~min}, 25 \%$ B over $1 \mathrm{~min}$, isocratic $25 \%$ B for $4 \mathrm{~min}, 50 \%$ B over $5 \mathrm{~min}, 80 \% \mathrm{~B}$ over $10 \mathrm{~min}$, isocratic $80 \%$ B for $7 \mathrm{~min}, 2 \%$ B over $2 \mathrm{~min}$, isocratic $2 \%$ B for $5 \mathrm{~min}$; flow rate: $0.6 \mathrm{~mL} / \mathrm{min}$; injection volume: $20 \mu \mathrm{L}$; sample concentration: $1 \mathrm{mg} / \mathrm{mL}$ in $50 \%$ methanol; UV-detection: $\lambda=280 \mathrm{~nm}$; internal standard: caffeine $(10 \mu \mathrm{g} / \mathrm{mL})$. LOD and LOQ were identified with LOD $=0.1 \mu \mathrm{g} / \mathrm{mL}$ and $\mathrm{LOQ}=0.5 \mu \mathrm{g} / \mathrm{mL}$.

\subsection{Green Tea Extraction (TXE)}

Camellia sinensis L., Theaceae, plant material was purchased from a local food market as dried, green tea leaves "gunpowder" ("Bio Grüntee Gunpowder", Alnatura, Bickenbach, Germany, LOT 65651). A sample of $18.04 \mathrm{~g}$ of the dried tea leaves was ground and extracted with $300 \mathrm{~mL}$ boiling water $\left(95^{\circ} \mathrm{C}\right)$ for $5 \mathrm{~min}$ with constant stirring. The mixture was cooled to room temperature, filtered (MN 615, Macherey Nagel, Düren, Germany), and $100 \mathrm{~mL}$ was purified with a XAD16N-packed column $(50 \mathrm{~mL})$. The column had been equilibrated with $500 \mathrm{~mL}$ water. Fifty milliliters of the mixture were applied and washed with $300 \mathrm{~mL}$ water, then eluted three times with $150 \mathrm{~mL} 90 \%$ ethanol. The eluate was dried in vacuum, freeze-dried and homogenized. The yield of green tea extract (TXE) from the sample was $4.4 \%$.

\subsection{Quantification of Caffeine in TXE}

The quantification of caffeine in the green tea extract (TXE) was performed with an Agilent 1200 series HPLC system (Model G1312B). HPLC conditions: column Synergi $4 \mu \mathrm{m}$ Polar-RP $80 \AA$, $250 \times 4.6 \mathrm{~mm}$ (Phenomenex); solvent system: A-0.1\% formic acid, B-acetonitrile; gradient profile: $2 \%-12 \%$ B over $5 \mathrm{~min}, 12 \%-30 \%$ B over $15 \mathrm{~min}, 30 \%-90 \%$ B over $3 \mathrm{~min}$, isocratic $90 \%$ B for $8 \mathrm{~min}$, $90 \%-2 \%$ over $1 \mathrm{~min}$, isocratic $2 \%$ B for $3 \mathrm{~min}$; flow rate: $0.8 \mathrm{~mL} / \mathrm{min}$; column temperature: $40{ }^{\circ} \mathrm{C}$; injection volume: $20 \mu \mathrm{L}$; sample concentration: $1 \mathrm{mg} / \mathrm{mL}$ in $50 \%$ methanol; UV-detection: $\lambda-270$, $325 \mathrm{~nm}$; internal standard: 3,4,5-trimethoxycinnamic acid $(20 \mu \mathrm{g} / \mathrm{mL})$. LOD and LOQ were identified with $\mathrm{LOD}=0.04 \mu \mathrm{g} / \mathrm{mL}$ and $\mathrm{LOQ}=0.1 \mu \mathrm{g} / \mathrm{mL}$.

\subsection{Identification of Catechins in TXE}

The catechins in the green tea extract were identified with a Perkin Elmer 200 series HPLC-UV (PerkinElmer, Waltham, MA, USA) equipped with a degasser, two micro pumps, an utosampler, and UV detector (785A) coupled to a PE Sciex API 2000 triple quad mass spectrometer (Sciex, Framingham, MA, USA). The HPLC conditions were partly adapted from [32]; HPLC conditions: column Luna $5 \mu \mathrm{m} \mathrm{C18} 100 \AA \AA 250 \times 4.6 \mathrm{~mm}$ (Phenomenex); column temperature: $40{ }^{\circ} \mathrm{C}$; solvent system: $\mathrm{A}-\mathrm{H}_{2} \mathrm{O} /$ methanol/formic acid: 74.7/25/0.3 (v/v/v), B-acetonitrile/formic acid: 99.7/0.3 $(v / v)$; gradient profile: isocratic $0 \%$ B for $8 \mathrm{~min}, 100 \%$ B over $24 \mathrm{~min}$, isocratic $100 \%$ B for $6 \mathrm{~min}$, $0 \%$ B over $4 \mathrm{~min}$, isocratic $0 \%$ B for $6 \mathrm{~min}$; flow rate: $0.5 \mathrm{~mL} / \mathrm{min}$; injection volume: $20 \mu \mathrm{L}$; sample concentration: $1 \mathrm{mg} / \mathrm{mL}$ in $50 \%$ methanol; UV-detection: $\lambda=270 \mathrm{~nm}$. ESI-MS/MS conditions: positive 
ion mode; ion spray voltage: $5500 \mathrm{~V}$; temperature $450{ }^{\circ} \mathrm{C}$; declustering potential: $61 \mathrm{~V}$; focusing potential: $370 \mathrm{~V}$; entrance potential: $12 \mathrm{~V}$; collision cell entrance potential: $14 \mathrm{~V}$.

\subsection{Artichoke Leaf Extraction (ALE)}

Cynara scolymus L., Asteraceae, plant material was purchased from a local pharmacy as dried and chopped leaves (Redwood, Bamberg, Germany, LOT 01160-033). A $12.3 \mathrm{~g}$ sample of leaves was homogenized and extracted with $300 \mathrm{~mL} 60 \%$ methanol for $3 \mathrm{~h}$ with stirring. After filtration (MN 615, Macherey Nagel, Düren, Germany), the extract was dried in a vacuum, freeze-dried and homogenized. This procedure yielded $26.8 \%$ of artichoke leaf extract (ALE).

\subsection{Identification of Chlorogenic Acids and Flavones in ALE}

The flavones and chlorogenic acids in the artichoke leaf extract were identified with a Perkin Elmer 200 series HPLC-UV coupled to a PE Sciex API 2000 triple quad electrospray mass spectrometer. HPLC conditions were the same as in the HPLC-UV analysis of caffeine in the TXE. ESI-MS/MS conditions: positive ion mode; ion spray voltage: $4700 \mathrm{~V}$; temperature $450{ }^{\circ} \mathrm{C}$; declustering potential: $50 \mathrm{~V}$; focusing potential: $340 \mathrm{~V}$; entrance potential: $10 \mathrm{~V}$; collision cell entrance potential: $19 \mathrm{~V}$; and for luteolin, declustering potential: $139 \mathrm{~V}$; focusing potential: $129 \mathrm{~V}$; entrance potential: $7 \mathrm{~V}$.

\subsection{Quantification of Dicaffeoylquinic Acids in ALE}

The HPLC-UV analysis of the dicaffeoylquinic acids in the artichoke leaf extract was performed on an Agilent 1200 series HPLC system. The HPLC conditions for the quantification of an unidentified dicaffeoylquinic acid as 3,4-dicaffeoylquinic acid were the same as in the HPLC-UV analysis of the TXE. Internal standard: caffeine $(10 \mu \mathrm{g} / \mathrm{mL})$. LOD and LOQ were identified with LOD $=0.04 \mu \mathrm{g} / \mathrm{mL}$ and $\mathrm{LOQ}=0.1 \mu \mathrm{g} / \mathrm{mL}$.

\subsection{Quantification of Flavones in $A L E$}

The HPLC-UV analysis of the flavones in the artichoke leaf extract was performed on an Agilent 1200 series HPLC system; HPLC conditions: column Luna $5 \mu \mathrm{m} \mathrm{C18} 100 \AA$, $250 \times 4.6 \mathrm{~mm}$ (Phenomenex); column temperature: $40{ }^{\circ} \mathrm{C}$; solvent system: $\mathrm{A}-\mathrm{H}_{2} \mathrm{O} /$ methanol/formic acid: 74.7/25/0.3 $(v / v / v), \mathrm{B}$-acetonitrile/formic acid: $99.7 / 0.3(v / v)$; gradient profile: isocratic $0 \% \mathrm{~B}$ for $8 \mathrm{~min}, 100 \%$ B over $30 \mathrm{~min}$, isocratic $100 \%$ B for $6 \mathrm{~min}, 0 \%$ B over $4 \mathrm{~min}$, isocratic $0 \%$ B for $6 \mathrm{~min}$; flow rate: $0.5 \mathrm{~mL} / \mathrm{min}$; injection volume: $50 \mu \mathrm{L}$; sample concentration: $1 \mathrm{mg} / \mathrm{mL}$ in $50 \%$ methanol; UV-detection: $\lambda=270,347 \mathrm{~nm}$; internal standard: caffeine $(10 \mu \mathrm{g} / \mathrm{mL})$. LOD and LOQ were identified with $\mathrm{LOD}=0.08 \mu \mathrm{g} / \mathrm{mL}$ and $\mathrm{LOQ}=0.3 \mu \mathrm{g} / \mathrm{mL}$.

\subsection{Ginger Extraction and Fractionation}

Zingiber officinale Roscoe, Zingiberaceae, plant material was obtained from a local food market as commercially available dried and ground rhizome (Ostmann, Dissen am Teutoburger Wald, Germany, LOT 3326AB) A $6.0 \mathrm{~g}$ sample of the powder was extracted with $200 \mathrm{~mL}$ of water for $1 \mathrm{~h}$, after which it was filtered (MN 615, Macherey Nagel, Düren, Germany) and freeze-dried. The yield of ginger powder extract (GPE) was $26.7 \%$, of which $530 \mathrm{mg}$ of this extract was reconstituted with $50 \mathrm{~mL}$ of $\mathrm{H}_{2} \mathrm{O}$ and the $\mathrm{pH}$ was adjusted to 3.0 with formic acid. The mixture was extracted three times with $50 \mathrm{~mL}$ ethyl acetate. The hydrophilic, 'watery' phase (GWE) was freeze-dried. The lipoid, organic phase (GLE) was dried over $\mathrm{NaSO}_{4}$ and then further dried in a vacuum. Weight comparison revealed that the GPE yielded $5 \%$ of the organic fraction (GLE) and $95 \%$ of the hydrophilic fraction (GWE).

\subsection{Quantification of [6]-Gingerol in Ginger Extracts (GPE, GLE, GWE)}

Quantification of [6]-gingerol from the three ginger extracts (GLE, GPE, GWE) followed the procedure of [66] on an Agilent 1200 series HPLC system (see above); HPLC conditions: column 
Symmetry 5 um C18 $100 \AA$, $4 \mu \mathrm{m} 250 \times 4.6$ mm (Waters, Milford, MA); solvent system: A- $0.1 \%$ formic acid, B-acetonitrile; gradient profile: $45 \%-50 \%$ B over $12 \min , 50 \%-65 \%$ B over $13 \mathrm{~min}, 65 \%-100 \%$ B over $20 \mathrm{~min}$, isocratic $100 \%$ B for $10 \mathrm{~min}, 100 \%-45 \%$ over $5 \mathrm{~min}$, isocratic $45 \%$ B for $10 \mathrm{~min}$; flow rate: $0.4 \mathrm{~mL} / \mathrm{min}$; injection volume: $8 \mu \mathrm{L}$; sample concentration: $1 \mathrm{mg} / \mathrm{mL}$ in methanol; UV-detection: $\lambda=230 \mathrm{~nm}$, internal standard: 3,4,5-trimethoxycinnamic acid $(11.8 \mu \mathrm{g} / \mathrm{mL})$. LOD and LOQ were identified with $\mathrm{LOD}=0.3 \mu \mathrm{g} / \mathrm{mL}$ and $\mathrm{LOQ}=0.9 \mu \mathrm{g} / \mathrm{mL}$.

\subsection{Cell Culture}

The large cell lung tumor xenograft cell line LXFL529L was cultivated in RPMI 1640 medium with $10 \%$ fetal calf serum (FCS) and $1 \%$ penicillin/streptomycin at $37^{\circ} \mathrm{C}, 5 \% \mathrm{CO}_{2}$ in humidified incubators. Medium, antibiotics and FCS were purchased from Gibco, Life Technologies, Carlsbad, CA, USA. Absence of mycoplasma contamination was verified regularly.

\subsection{4. cAMP-Specific PDE Activity Assay}

Phosphodiesterases were isolated from LXFL529L cells. Appearing in the particulate and cytosol of this cell line, cAMP hydrolyzing activity belongs mostly to PDE family 4 [67]. Cells were cultivated for $48 \mathrm{~h}, 10^{6}$ cells per culture dish, and then washed with $2 \times 1 \mathrm{~mL}$ phosphate buffered saline $\left(\mathrm{pH}=7.4,4^{\circ} \mathrm{C}\right)$ and harvested with $2 \times 200 \mu \mathrm{L}$ RUN III buffer $\left(100 \mathrm{mM}\right.$ Tris/HCl 7.4, $20 \mathrm{mM} \mathrm{MgCl}_{2}$, $0.2 \mathrm{mM}$ EDTA, $10 \mathrm{mM}$ benzamidine, $1 \mathrm{mM} \beta$-mercaptoethanol and a protease inhibitor mix). The harvested cells underwent ultrasound lysis, after which the supernatant $\left(12,000 \mathrm{rcf}, 15 \mathrm{~min}, 4^{\circ} \mathrm{C}\right)$, which contains the cytosolic phosphodiesterases, was collected and diluted with RUN III buffer to $4.5 \mathrm{~mL}$. The inhibitory effects of the different extracts on PDE were measured according to Montoya et al. [8]. Fifty microliters of the cytosolic fraction, $50 \mu \mathrm{L}$ of the sample and $50 \mu \mathrm{L}$ of cAMP Mix (30 mM Tris/ $\mathrm{HCl} \mathrm{pH} 7.4,9 \mathrm{mM} \mathrm{MgCl} 2,3$ mM 5 AMP, $3 \mu \mathrm{M}$ cAMP, $2.6 \mu \mathrm{Ci} / \mathrm{mL}\left[2,8-{ }^{3} \mathrm{H}\right]-\mathrm{cAMP}$ ) were mixed over ice and incubated for $10 \mathrm{~min}$ at $37^{\circ} \mathrm{C}$. The reaction was then stopped over ice, and $250 \mu \mathrm{L}$ of $\mathrm{ZnSO}_{4}(0.266 \mathrm{M})$ and $\mathrm{Ba}(\mathrm{OH})_{2}(0.266 \mathrm{M})$ were added to the mixture. Then, $450 \mu \mathrm{L}$ of the supernatant was mixed with $4 \mathrm{~mL}$ of a scintillation cocktail and the resulting radioactivity was measured with a liquid scintillation counter (TRI-CARB 2100 TR, Packard, Meriden, CT, USA). Samples were dissolved in either water or DMSO, which did not exceed a final concentration of $1 \%$ or $10 \%$, respectively. The selective PDE 4 inhibitor rolipram $(10 \mu \mathrm{M})$ served as a positive control. To compare with previous experiments, test concentrations of extracts and single substances were chosen in a similar range of previous studies (extracts $<10 \mathrm{mg} / \mathrm{mL}$, single substances $<500 \mu \mathrm{g} / \mathrm{mL}$ ) $[10,68]$.

\subsection{Statistical Analysis}

The results of cAMP-specific PDE activity assay were presented as the mean \pm standard deviation of at least three independent experiments. Statistical analyses were carried out with Excel 2013 software. The differences between samples and solvent control were evaluated by analysis of variance (one-side Fisher's $F$-test, confidence interval $p<0.05)$ followed by a one-sided Student's $t$-test. The following confidence intervals are represented as either one, two, or three stars in the figures: $p<0.05$ : *; $p<0.01:^{* *} ; p<0.001:^{* * *}$.

\section{Results}

The extracts of strawberry tree (Arbutus unedo L., Ericaceae) fruits (SFE), green tea (Camellia sinensis L., Theaceae) leaves (TXE), artichoke (Cynara scolymus L., Asteraceae) leaves (ALE) and ginger (Zingiber officinale Roscoe, Zingiberaceae) rhizome (GPE) were tested for their in-vitro ability to inhibit cAMP-specific PDE activity in LXFL529L cells expressing mostly PDE IV isoforms. The inhibitory potentials of the extracts were compared to the selective PDE IV inhibitor rolipram. Data are presented as $\mathrm{T} / \mathrm{C}$ (test over control) in percent of a solvent control. 


\subsection{Strawberry Tree Fruit Extraction (SFE) and Inhibitory Effect on PDE Activity In Vitro}

Extraction of the strawberry tree (Arbutus unedo) fruits followed by purification with a XAD16N column yielded less than $1 \%$ of polyphenol-enriched SFE as a red-colored, amorphous and hydrophobic powder that contained a total arbutin concentration of $20.0 \pm 1.3 \mu \mathrm{g} / \mathrm{mg}$. A chromatogram of the SFE is shown in Figure 1.

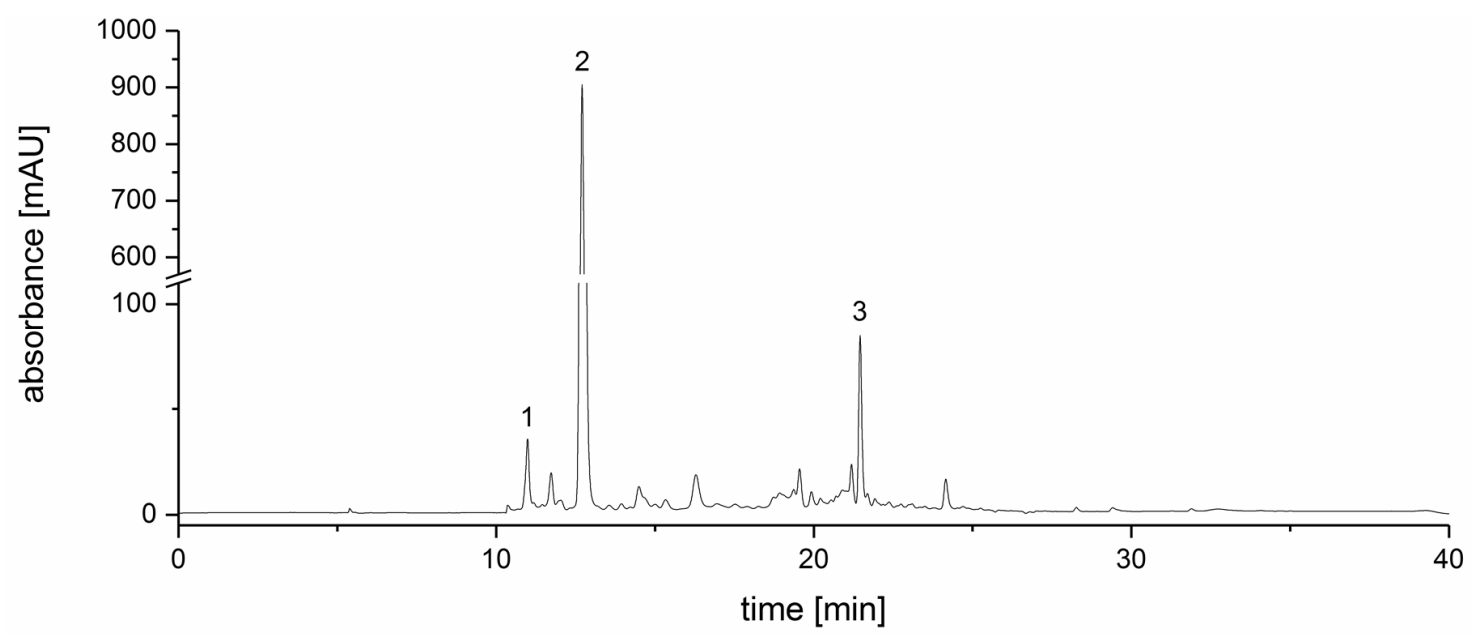

Figure 1. HPLC-UV chromatogram $(\lambda=280 \mathrm{~nm}$ ) of the strawberry tree fruit extract (SFE) (Arbutus unedo). The three peaks represent arbutin (1), galloyl quinic acid (2) and the internal standard caffeine (3).

The SFE showed no in-vitro inhibitory effect on PDE at levels below $5 \mathrm{mg} / \mathrm{mL}$ (see Figure 2a). However, when the concentration was increased to $10 \mathrm{mg} / \mathrm{mL}$, it showed a PDE inhibition of $23.6 \%$ $(p<0.05)$. When this inhibition was compared to that of the selective PDE IV inhibitor rolipram at a concentration of $10 \mu \mathrm{M}(2.8 \mu \mathrm{g} / \mathrm{mL}, 70.5 \%)$, the effect was rather negligible. An $\mathrm{IC}_{50}$ value was not determined due to poor inhibition of the SFE $(<50 \%)$. Furthermore, when PDE was incubated with pure arbutin, there was no inhibition at all in tested concentrations up to $500 \mu \mathrm{g} / \mathrm{mL}(1.8 \mathrm{mM})$ (Figure 2b).

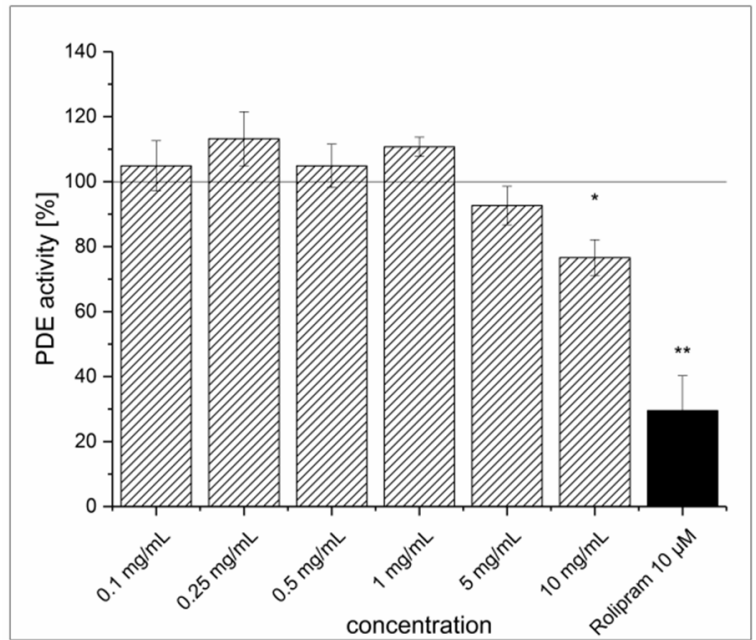

(a)

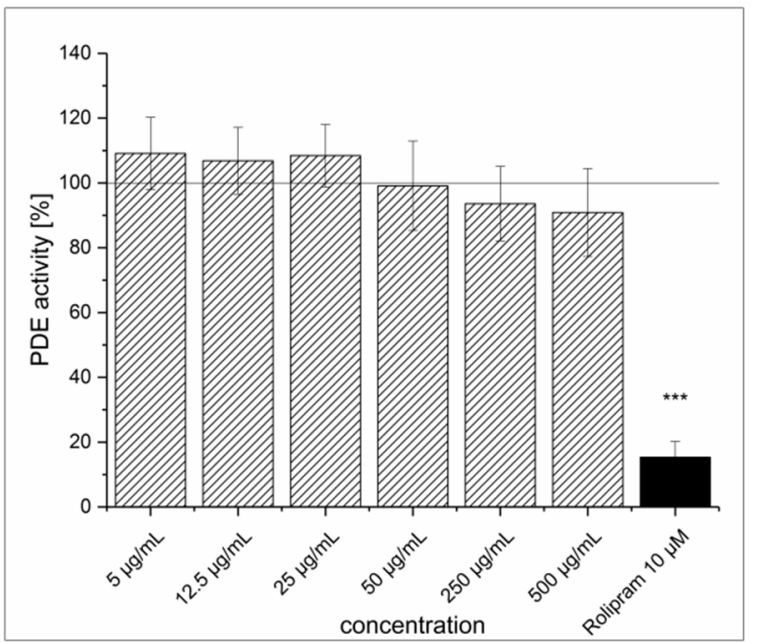

(b)

Figure 2. cAMP-specific phosphodiesterase (PDE) activity following incubation with strawberry tree fruit extract (SFE) (a) and purified arbutin (b). Data are presented as the mean \pm standard deviation of three independent experiments. The significance of differences between sample and control was assessed with a Student's $t$-test. Confidence intervals: ${ }^{*} p<0.05 ;{ }^{* *} p<0.01 ;{ }^{* *} p<0.001$. 


\subsection{Green Tea Leaves Extraction (TXE) and Inhibitory Effect on PDE Activity In Vitro}

The extraction procedure of green tea leaves (Camellia sinensis) and purification of the polyphenolenriched fraction with a XAD16N column yielded ca. 9\% of TXE as a green-colored, amorphous and hydrophobic powder. The TXE did not inhibit PDE activity at any of the tested concentrations and while an inhibition was expected, it showed an increase of PDE activity (see Figure 3a). The content of caffeine, which is a well-known PDE inhibitor, in the TXE was $131.6 \pm 5.0 \mu \mathrm{g} / \mathrm{mg}$. The inhibitory effect of caffeine on PDE activity was concentration dependent and the maximum PDE inhibition of $40 \%$ was observed at concentrations of $250 \mu \mathrm{g} / \mathrm{mL}$ and $500 \mu \mathrm{g} / \mathrm{mL}$ (see Figure 3b). Earlier studies showed the $\mathrm{IC}_{50}$ for caffeine was determined to be $0.9 \pm 0.1 \mathrm{mg} / \mathrm{mL}(4.8 \pm 0.6 \mathrm{mM}$ - data not shown [68] $)$ under the same assay conditions.

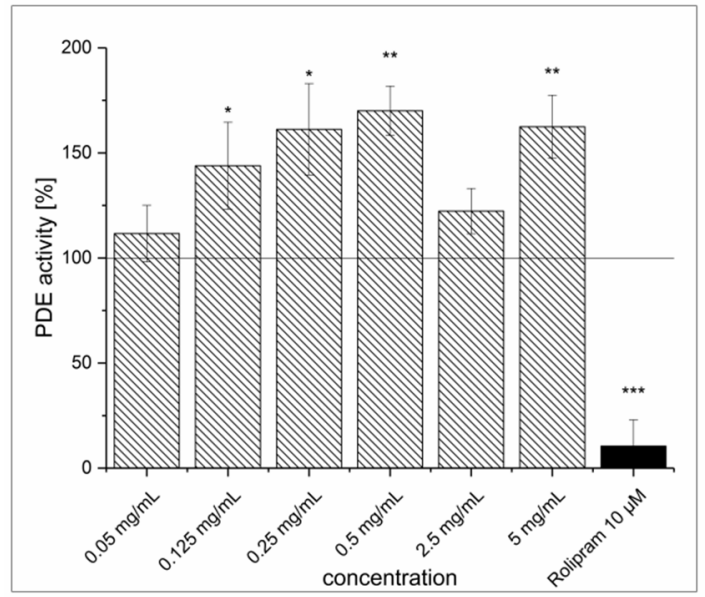

(a)

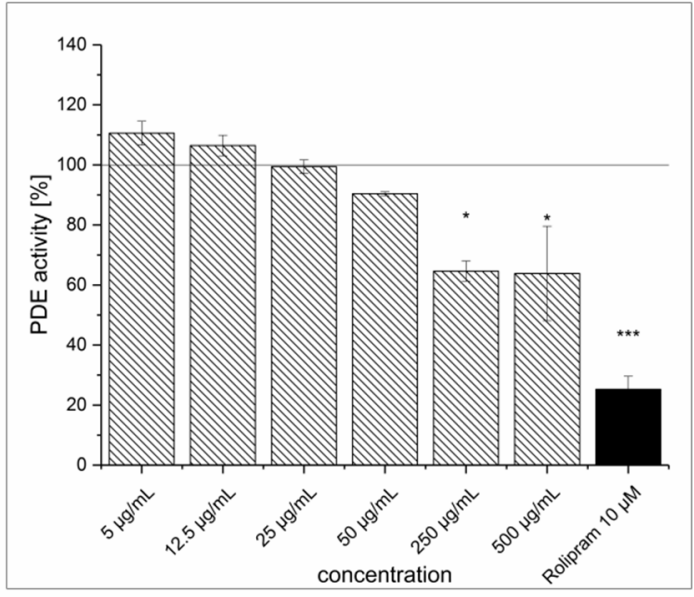

(b)

Figure 3. cAMP-specific phosphodiesterase (PDE) activity following incubation with green tea extract (TXE) (a) and caffeine (b). Data are presented as the mean \pm standard deviation of three independent experiments. The significance of differences between sample and control was assessed with a Student's $t$-test. Confidence intervals: ${ }^{*} p<0.05 ;{ }^{* *} p<0.01 ;{ }^{* *} p<0.001$.

\subsection{Artichoke Leaves Extraction (ALE) and Inhibitory Effect on PDE Activity In Vitro}

The extraction of artichoke (Cynara scolymus) leaves yielded almost $27 \%$ of ALE as a brown-colored, amorphous powder. The ALE concentrations higher than $0.5 \mathrm{mg} / \mathrm{mL}$ showed significant inhibition of PDE activity $\left(\mathrm{IC}_{50}=0.9 \pm 0.1 \mathrm{mg} / \mathrm{mL}\right)$. At the highest tested concentrations $(5$ and $10 \mathrm{mg} / \mathrm{mL})$, ALE showed levels of inhibition comparable to the positive control rolipram (see Figure $4 \mathrm{a}$ ). The artichoke flavones luteolin, apigenin and luteolin-7-O-glucoside showed poor solubility (in 30\% DMSO) and thus limited the concentrations to be tested. The highest concentrations of apigenin, luteolin-7-O-glucoside and luteolin-7-O-glucuronide used in the assay were $25 \mu \mathrm{g} / \mathrm{mL}, 35 \mu \mathrm{g} / \mathrm{mL}$ and $500 \mu \mathrm{g} / \mathrm{mL}$, respectively, and none of these flavones showed any PDE inhibition. Data for luteolin-7-O-glucuronide are shown in Figure 4b. Conversely, it could be confirmed that unglycosylated luteolin acted as a strong PDE inhibitor at low concentrations $\left(\mathrm{IC}_{50}=11.8 \pm 2.9 \mu \mathrm{g} / \mathrm{mL}\right)$, shown in Figure 4c. Unfortunately, this flavone aglycone was not present in the extract. The predominant chlorogenic acid in the ALE was 5-caffeoylquinic acid (5-CQA), but a dicaffeoylquinic acid (DiCQA), where the positions of the esterification were not identified, was also present at $2.5 \pm 0.5 \mu \mathrm{g} / \mathrm{mg}$. The supposed ALE constituents 1,3-dicaffeoylquinic acid and 1,5-dicaffeoylquinic acid were not commercially available, so an isomer, 3,4-dicaffeoylquinic acid, was used for the PDE inhibition experiments. As 3,4-dicaffeoylquinic acid concentrations increased to $500 \mu \mathrm{g} / \mathrm{mL}(\sim 1 \mathrm{mM})$, PDE activity decreased almost 50\% (see Figure 4d). 


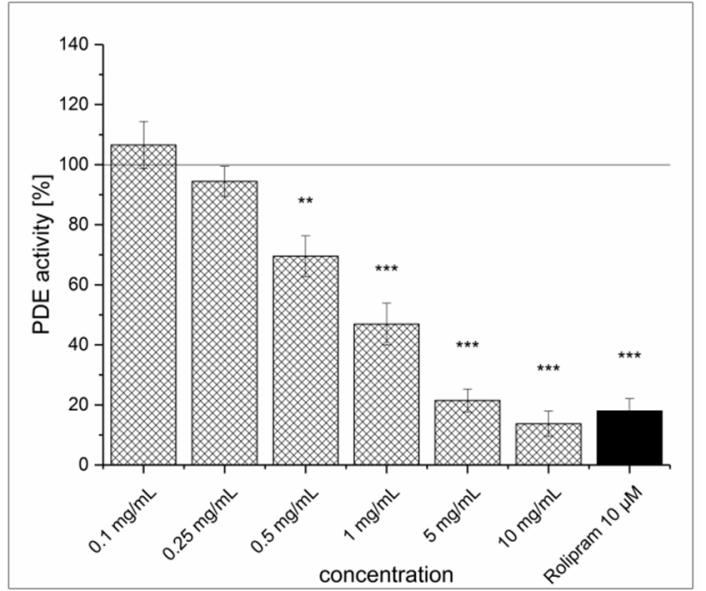

(a)

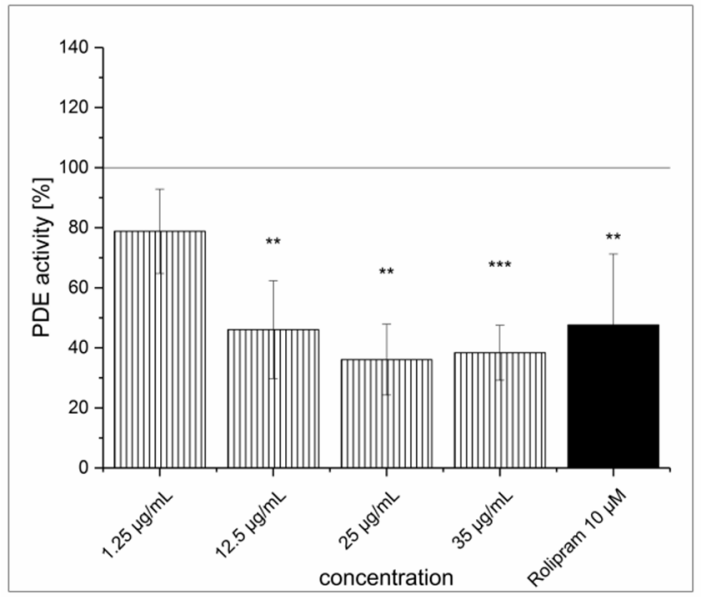

(c)

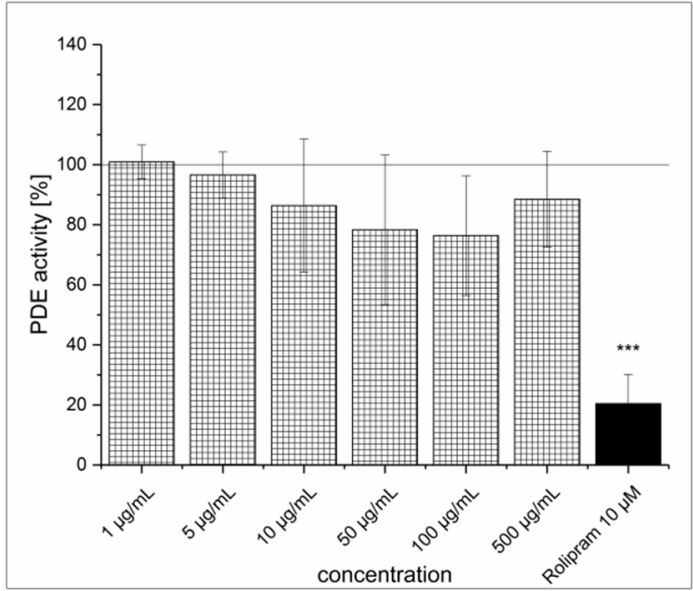

(b)

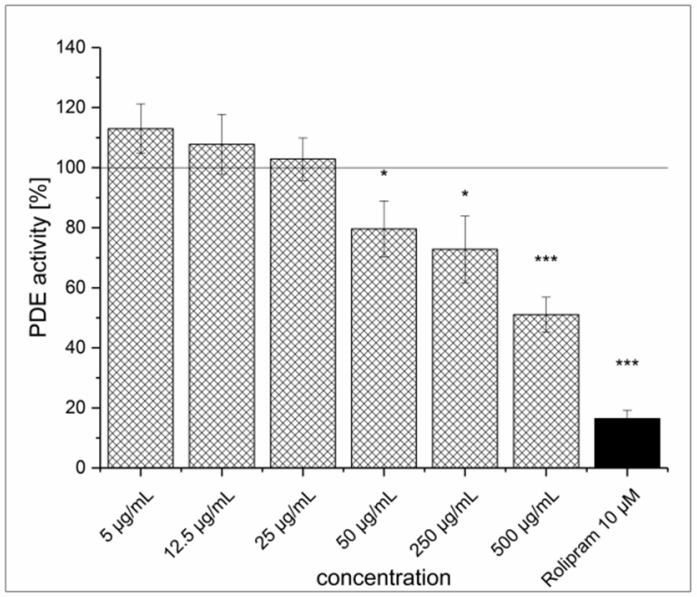

(d)

Figure 4. cAMP-specific phosphodiesterase (PDE) activity following incubation with artichoke leaf extract (ALE) (a), luteolin-7-O-glucuronide (b), luteolin (c) and 3,4-dicaffeoylquinic acid (d). Data are presented as the mean \pm standard deviation of three independent experiments. The significance of differences between sample and control was assessed with a Student's $t$-test. Confidence intervals: ${ }^{*} p<0.05 ;{ }^{* *} p<0.01 ;{ }^{* * *} p<0.001$.

\subsection{Dried Ginger Rhizome Extraction (GPE) and Inhibitory Effect on PDE Activity In Vitro}

The extraction procedure of powdered ginger rhizome (Zingiber officinale Roscoe) resulted in a light brown, amorphous powder with a [6]-gingerol content of $10.0 \pm 0.6 \mu \mathrm{g} / \mathrm{mg}$. The GPE inhibited PDE activity significantly (see Figure $5 \mathrm{a})$. At the highest tested concentration $(10 \mathrm{mg} / \mathrm{mL})$, the inhibitory effect of GPE ( $\mathrm{IC}_{50}=1.7 \pm 0.2 \mathrm{mg} / \mathrm{mL}$ ) was comparable to the positive control $(85.9 \% \mathrm{vs} .86 .9 \%)$. Furthermore, [6]-gingerol also had an inhibitory effect, as at a concentration of $500 \mu \mathrm{g} / \mathrm{mL}(\sim 1.7 \mathrm{mM})$ it decreased PDE activity by $38.2 \%$ (see Figure 5b). Considering that [6]-gingerol content in GPE was $1 \%$, the observed PDE inhibition cannot result exclusively from [6]-gingerol. A crude fractionation of the GPE with liquid-liquid extraction was performed to determine whether the PDE-inhibiting compounds were hydrophilic or lipophilic. The fractionation resulted in a lipoid (GLE) fraction that accounted for 5\% and a hydrophilic (GWE) fraction that accounted for 95\% of the GPE. Both fractions were able to inhibit PDE, but the lipoid fraction was a more potent inhibitor $\left(\mathrm{IC}_{50}=455 \pm 19 \mu \mathrm{g} / \mathrm{mL}\right)$ than the hydrophilic fraction $\left(\mathrm{IC}_{50}=10.5 \pm 1.9 \mathrm{mg} / \mathrm{mL}\right.$ ) (see Figure $5 \mathrm{c}, \mathrm{d}$ ). The [6]-gingerol content of the GLE fraction was $205.4 \pm 11.7 \mu \mathrm{g} / \mathrm{mg}$, whereas no gingerol was identified in the GWE fraction (LOD $=0.3 \mu \mathrm{g} / \mathrm{mg}$ ). However, [6]-gingerol represented only $20 \%$ of GLE fraction, so the inhibition of PDE cannot be solely linked to [6]-gingerol. 


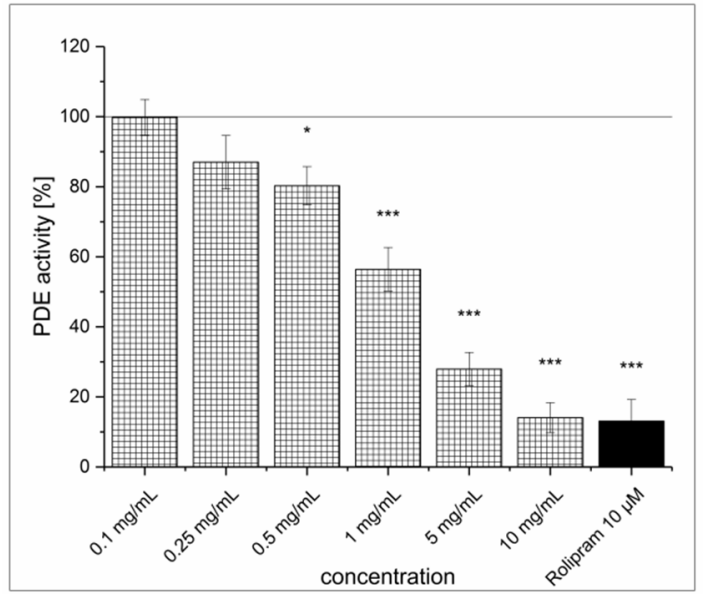

(a)

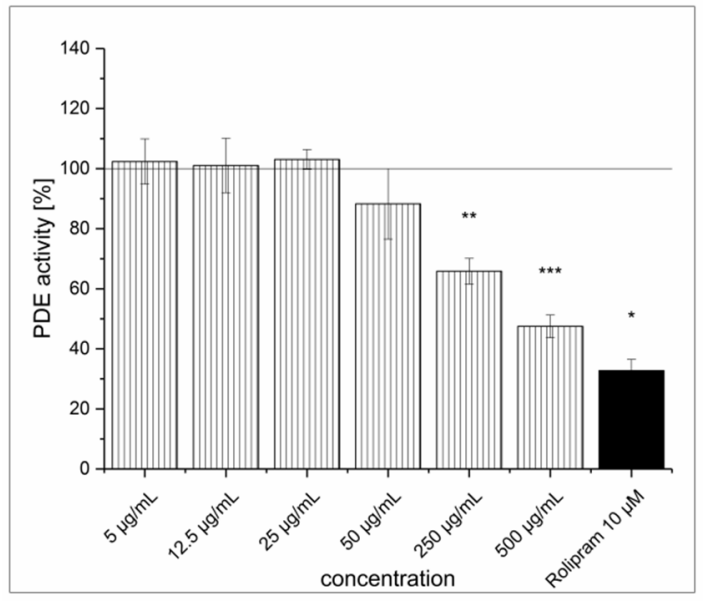

(c)

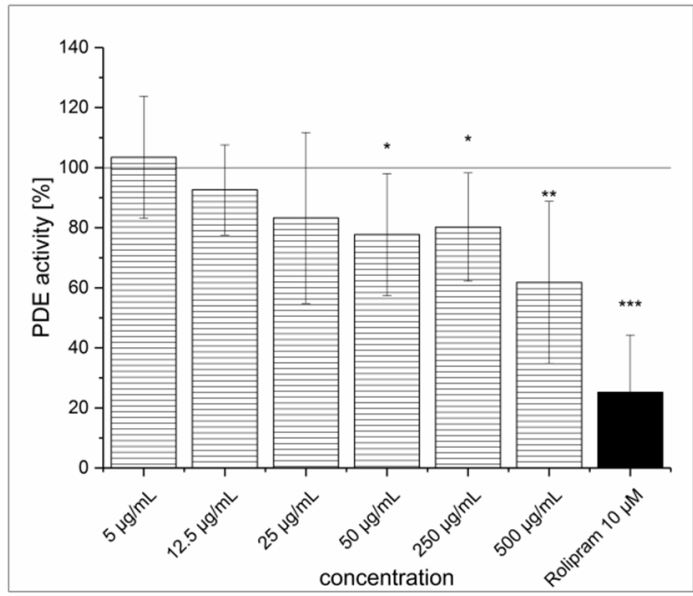

(b)

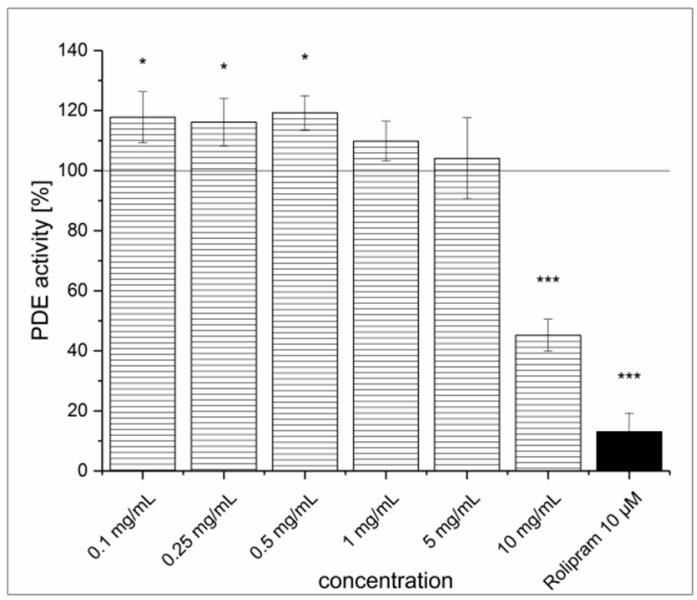

(d)

Figure 5. cAMP-specific phosphodiesterase (PDE) activity following incubation with ginger powder extract (GPE) (a), [6]-gingerol (b), ginger lipoid fraction (GLE) (c) and ginger hydrophilic fraction (GWE) (d). Data are presented as the mean \pm standard deviation of three independent experiments. The significance of differences between sample and control was assessed with a Student's $t$-test. Confidence intervals: ${ }^{*} p<0.05 ;{ }^{* *} p<0.01 ;{ }^{* * *} p<0.001$.

\section{Discussion}

Both ginger extract GPE and artichoke extract ALE demonstrated strong PDE inhibitory potential in the frame of this study. Furthermore, PDE inhibition was observed with [6]-gingerol, the lead substance in ginger, as well as with luteolin, caffeine and 1,3-diCQA. Contrary to that, incubation with tea extract TXE, strawberry tree fruit extract SFE and arbutin did not result in PDE inhibition.

Certain Arbutus unedo constituents, such as anthocyanins and catechins, have been reported to inhibit PDEs, although the inhibitory effect of catechins was shown to be marginal [11-15]. Anthocyanins are strong inhibitors of PDEs and, therefore, it was expected that the SFE would have a strong inhibitory effect on PDE. A plausible explanation for the lack of inhibition could be a low anthocyanin content in the SFE, which was not verified. Since the extraction was performed with $2 \%$ formic acid, which has been shown to be suitable in the extraction of anthocyanins [69], a loss of anthocyanins during extraction can be excluded. A low anthocyanin content in the SFE could partly result from the raw material. Previous reports have presented an unusually wide range for the anthocyanin content in fresh fruits, with values of $0.51 \mathrm{mg}$ [23], $3.77 \mathrm{mg}$ [22] and even $517.40 \mathrm{mg}$ [70] per $100 \mathrm{~g}$ of fresh fruit. A possible explanation for this wide variation is that the chemical composition of the fruit changes at different stages of ripeness [71]. The antihypertensive [17-19] and 
antithrombotic [20,21] properties of Arbutus unedo indicate that compounds in the fruit could inhibit PDEs, but this study's experiments with either the polyphenol-enriched extract SFE or arbutin were not able to confirm this. Fruits of Arbutus unedo are rich in biologically active compounds such as gallic acid derivatives, proanthocyanidins, anthocyanins and catechins, all of which can contribute to the reported effects mentioned above. However, PDE inhibition seems to not be a mechanism of action (MOA). Food that contain arbutin should be used with care, despite the traditional therapeutic use of plant-derived arbutin in urethral infections. Sometimes hydroquinone is released when arbutin undergoes deglycosylation by gut microbiota [72]. Hydroquinone is mutagenic and was assessed by the IARC as "not classifiable as to its carcinogenicity to humans (group 3)" due to inadequate evidence of carcinogenicity in humans.

As with SFE, it was hypothesized that Camellia sinensis extract TXE would inhibit PDE activity due to its chemical composition and recognized physiological effects, especially an antithrombotic effect [36-38]. It was expected that a TXE concentration of $5 \mathrm{mg} / \mathrm{mL}$, with caffeine content of almost $0.7 \mathrm{mg} / \mathrm{mL}$, would inhibit PDE activity, but this was not the case. This finding, together with the unusually high PDE activity, suggests that caffeine-mediated PDE inhibition in TXE is relatively weak, or may be diminished by an unknown PDE-activating mechanism. Furthermore, catechin and epicatechin have been shown to be weak PDE inhibitors when compared to other flavonoids [13,14]. Contrary to these findings, catechin and epicatechin were also found to have a stimulatory effect on PDEs with $\mathrm{EC}_{50}$ values of 240 and $136 \mu \mathrm{M}$, respectively [14]. The catechins identified in the TXE through HPLC-MS/MS were identical to those previously reported in literature [26-32,73,74], and their occurrence, based on extracted ion chromatogram area ratios, was EGC >>EC $>$ EGCG $\approx \mathrm{GC}>$ ECG $>C$. The total catechin content of the TXE was not determined in the frame of these investigations. As catechins have a weak inhibitory effect on PDEs, a plausible explanation for the absence of PDE inhibition by TXE may be low catechin concentrations in the TXE, possibly in combination with a PDE-activating mechanism that counteracts the inhibitory effect of caffeine. According to the TXE results, the physiological effects of Camellia sinensis cannot be explained by PDE inhibition.

Artichoke (Cynara scolymus) is known to contain flavones, mainly apigenin and luteolin glycosides [44-46], which have been reported to act as PDE inhibitors [12-14]. However, in this study no effect was observed when luteolin glycosides were tested. Furthermore, luteolin, which was demonstrated to be a strong PDE inhibitor in accordance with the literature, could not be found in the PDE-inhibiting extract. These circumstances make the interpretation of the PDE inhibition observed with artichoke extract ALE difficult. Chlorogenic acids are another group of phenolic compounds present in artichokes with physiological relevancy. Previous studies attribute part of the PDE inhibitory effect of the chlorogenic acid 5-CQA to a $\mathrm{pH}$ shift [8]. The involvement of $\mathrm{pH}$ change in PDE inhibition can be neglected as $\mathrm{pH}$ remained constant during assays with 3,4-DiCQA in these experiments. Hence, ALE showed a fairly strong inhibitory effect on PDE, possibly through dicaffeoylquinic acids and/or flavones that were not identified in the extract yet. The antihypertensive effect of Cynara scolymus [41] may result from PDE inhibition, but further investigations are necessary to confirm this role. As the content of phenolic compounds is higher in artichoke leaves than in the edible flower buds [47], the effect of consuming artichokes or drinking teas from artichoke leaves on PDE activity should be of relevance.

Earlier publications have not reported that ginger (Zingiber officinale) extracts, or [6]-gingerol, can inhibit PDE [60-62]. However, three potential PDE inhibitors from the Zingiberaceae family, one of which was from Zingiber officinale, were recently identified through in-silico screening [63]. These results provide further evidence that prepared ginger extract has the potential to inhibit PDE activity. A study where volunteers consumed different doses of a dietary ginger supplement found the $\mathrm{C}_{\max }$ of [6]-gingerol metabolites reached a maximum of $4.4 \mu \mathrm{g} / \mathrm{mL}$ [75], while in this study $\mathrm{IC}_{50}$ values of the in-vitro PDE inhibition were 100-fold higher. This raises the question whether under physiological conditions a PDE-inhibiting effect from [6]-gingerol is likely. Nevertheless, ginger rhizome presumably contains further lipophilic PDE inhibitors with even higher potential than [6]-gingerol, as was 
concluded when the lipoid fraction demonstrated a stronger PDE-inhibiting potential than [6]-gingerol. Because these substances are unknown, their identification and pharmacokinetics are of strong interest. The inhibition of PDE by ginger extracts in vivo may have a synergistic effect on the physiological effects mediated by cyclooxygenase inhibition, but this should be investigated further.

The interpretation of results of this study faces some limitations due to the different approaches used for each of the four extracts. Unfortunately, some known PDE inhibitors were not quantified in the extracts showing no PDE inhibition, for example, anthocyanins in SFE and catechins in TXE. Thus, explaining why these extracts possessed no inhibitory effect on PDE activity with a low concentration of these PDE inhibitors in the extract is only hypothetical. Furthermore, the results for luteolin, 3,4-diCQA and [6]-gingerol showed that single-substance testing only led to vague conclusions about the active compounds in ALE and GPE. An activity-guided fractionation should therefore be preferred in contrast to single-substance testing to identify responsible compounds in PDE-inhibiting extracts. This may be reversed with simple screening studies.

\section{Conclusions}

This study was able to demonstrate the PDE-inhibiting potential of artichoke and ginger extracts for the first time. The motivation to investigate selected food extracts on their ability to inhibit PDE was triggered by previous reports of physiological effects that may result from PDE inhibition, for example, antithrombotic and antihypertensive effects. The results of this study are summarized in Table 1 Extracts from Arbutus unedo and Camellia sinensis did not show notable inhibition of PDE in our experiments, and thus the reported physiological effects of these plants do not result from underlying PDE inhibition. On the other hand, extract from artichoke (Cynara scolymus) showed significant PDE inhibition. The results of this study suggest that flavones and caffeoylquinic acids are involved in the PDE inhibition of ALE. Whether PDE inhibition is a mechanism of action in the reported physiological effects of artichoke should be addressed in future studies. Furthermore, extract from ginger (Zingiber officinale) also had an inhibitory effect on PDE activity. It is likely that, next to [6]-gingerol, certain unidentified lipophilic compounds are of relevance for the observed effect. It should be investigated in the future whether PDE inhibition can be achieved under physiological conditions with ginger extracts. Furthermore, the results should be validated, and possible beneficial in-vivo effects of artichoke and ginger are to be investigated.

Table 1. Inhibition $\left(\mathrm{IC}_{50}\right)$ of cAMP-specific phosphodiesterase (PDE) by the four extracts and their constituent compounds. The content values are presented as the mean \pm standard deviation of two independent experiments. Percentages in brackets represent inhibition at highest concentration.

\begin{tabular}{|c|c|c|c|c|c|c|}
\hline Extracted Plant & $\begin{array}{l}\text { Extracted } \\
\text { Part }\end{array}$ & $\begin{array}{c}\mathrm{IC}_{50} \\
(\mathrm{mg} / \mathrm{mL})\end{array}$ & Lead Substance & $\begin{array}{l}\text { Content } \\
(\mu \mathrm{g} / \mathrm{mg})\end{array}$ & $\mathrm{IC}_{50}$ & \\
\hline $\begin{array}{c}\text { Arbutus unedo } \\
\text { (strawberry tree) }\end{array}$ & fruit & n.d. ${ }^{1}$ & arbutin & $20.0 \pm 1.3$ & n.d. ${ }^{1}$ & n.d. ${ }^{1}$ \\
\hline $\begin{array}{l}\text { Camellia sinensis } \\
\text { (tea) }\end{array}$ & $\begin{array}{l}\text { dried } \\
\text { leaves }\end{array}$ & n.d. ${ }^{1}$ & caffeine & $131.6 \pm 5.0$ & $0.9 \pm 0.1 \mathrm{mg} / \mathrm{mL}$ & $\begin{array}{c}4.8 \pm 0.6 \\
\mathrm{mM}\end{array}$ \\
\hline $\begin{array}{c}\text { Cynara scolymus } \\
\text { (artichoke) }\end{array}$ & $\begin{array}{l}\text { dried } \\
\text { leaves }\end{array}$ & $0.9 \pm 0.1$ & $\begin{array}{c}\text { 3,4-diCQA } \\
\text { luteolin } \\
\text { luteolin-7-O-glucuronide } \\
\text { luteolin-7-O-glucoside } \\
\text { apigenin }\end{array}$ & $\begin{array}{l}2.5 \pm 0.5 \\
<0.08 \\
2.7 \pm 0.3 \\
4.9 \pm 1.0 \\
<0.08\end{array}$ & $\begin{array}{c}>500 \mu \mathrm{g} / \mathrm{mL}(49 \%) \\
11.8 \pm 2.9 \mu \mathrm{g} / \mathrm{mL} \\
\text { n.d. }{ }^{1} \\
\text { n.d. }{ }^{1} \\
\text { n.d. }{ }^{1}\end{array}$ & $\begin{array}{l}>1.0 \mathrm{mM} \\
41 \pm 10 \mu \mathrm{M} \\
\text { n.d. }{ }^{1} \\
\text { n.d. }{ }^{1} \\
\text { n.d. }{ }^{1}\end{array}$ \\
\hline $\begin{array}{l}\text { Zingiber officinale } \\
\text { (ginger) }\end{array}$ & $\begin{array}{l}\text { dried } \\
\text { rhizome }\end{array}$ & $1.7 \pm 0.2$ & $\begin{array}{c}\text { [6]-gingerol } \\
\text { lipoid fraction (GLE) } \\
\text { hydrophilic fraction (GWE) }\end{array}$ & $\begin{array}{l}10.0 \pm 0.6 \\
\quad \sim 50 \\
\sim 950\end{array}$ & $\begin{array}{c}>500 \mu \mathrm{g} / \mathrm{mL}(38 \%) \\
455 \pm 19 \mu \mathrm{g} / \mathrm{mL} \\
10.5 \pm 1.9 \mathrm{mg} / \mathrm{mL}\end{array}$ & $\begin{array}{c}>1.7 \mathrm{mM} \\
- \\
-\end{array}$ \\
\hline
\end{tabular}

${ }^{1}$ n.d.- not determined due to solubility limitations or weak inhibitory effect. 
Acknowledgments: The authors would like to thank Heinz-Herbert Fiebig (Freiburg) for the LXFL529L cell line and Gina Alejandra Montoya Parra for the determination of the $\mathrm{IC}_{50}$ of caffeine. We would like to thank the University of Kaiserslautern for providing a Ph.D. grant.

Author Contributions: T.R. supervised laboratory work of coauthors O.P., S.H.-H., J.K., K.S. and wrote the manuscript. O.P. performed the experiments and analyzed the data with artichoke, S.H.-H. with ginger, J.K. with green tea, K.S. with strawberry tree. E.R. supervised the project.

Conflicts of Interest: The authors declare that they have no conflicts of interest.

\section{References}

1. Boswell-Smith, V.; Spina, D.; Page, C.P. Phosphodiesterase inhibitors. Br. J. Pharmacol. 2006, 147, $252-257$. [CrossRef] [PubMed]

2. Gresele, P.; Momi, S.; Falcinelli, E. Anti-platelet therapy: Phosphodiesterase inhibitors. Br. J. Clin. Pharmacol. 2011, 72, 634-646. [CrossRef] [PubMed]

3. Rybalkin, S.D.; Yan, C.; Bornfeldt, K.E.; Beavo, J.A. Cyclic GMP phosphodiesterases and regulation of smooth muscle function. Circ. Res. 2003, 93, 280-291. [CrossRef] [PubMed]

4. Barnes, P.J. Theophylline: New perspectives for an old drug. Am. J. Respir. Crit. Care Med. 2003, 167, 813-818. [CrossRef] [PubMed]

5. Giembycz, M.A.; Field, S.K. Roflumilast: First phosphodiesterase 4 inhibitor approved for treatment of COPD. Drug Des. Dev. Ther. 2010, 4, 147-158. [CrossRef]

6. Rall, T.; Sutherland, E.W. Formation of a cyclic adenine ribonucleotide by tissue particles. J. Biol. Chem. 1958, 232, 1065-1076. [PubMed]

7. Butcher, R.; Sutherland, E. Adenosine $3^{\prime}, 5^{\prime}$-phosphate in biological materials. J. Biol. Chem. 1962, 237, 1244-1250. [PubMed]

8. Montoya, G.A.; Bakuradze, T.; Eirich, M.; Erk, T.; Baum, M.; Habermeyer, M.; Eisenbrand, G.; Richling, E. Modulation of $3^{\prime}, 5^{\prime}$-cyclic AMP homeostasis in human platelets by coffee and individual coffee constituents. Br. J. Nutr. 2014, 112, 1427-1437. [CrossRef] [PubMed]

9. Riedel, A.; Dieminger, N.; Bakuradze, T.; Lang, R.; Montoya Parra, G.A.; Hochkogler, C.M.; Winkler, S.; Bytof, G.; Lantz, I.; Stiebitz, H.; et al. A 4-week consumption of medium roast and dark roast coffees affects parameters of energy status in healthy subjects. Food Res. Int. 2014, 63 Part C, 409-419. [CrossRef]

10. Röhrig, T.; Liesenfeld, D.; Richling, E. Identification of a Phosphodiesterase-Inhibiting Fraction from Roasted Coffee (Coffea arabica) through Activity-Guided Fractionation. J. Agric. Food Chem. 2017, 65, 3792-3800. [CrossRef] [PubMed]

11. Marko, D.; Puppel, N.; Tjaden, Z.; Jakobs, S.; Pahlke, G. The substitution pattern of anthocyanidins affects different cellular signaling cascades regulating cell proliferation. Mol. Nutr. Food Res. 2004, 48, 318-325. [CrossRef] [PubMed]

12. Ko, W.-C.; Shih, C.-M.; Lai, Y.-H.; Chen, J.-H.; Huang, H.-L. Inhibitory effects of flavonoids on phosphodiesterase isozymes from guinea pig and their structure-activity relationships. Biochem. Pharmacol. 2004, 68, 2087-2094. [CrossRef] [PubMed]

13. Beretz, A.; Anton, R.; Stoclet, J. Flavonoid compounds are potent inhibitors of cyclic AMP phosphodiesterase. Experientia 1978, 34, 1054-1055. [CrossRef] [PubMed]

14. Kuppusamy, U.; Das, N. Effects of flavonoids on cyclic AMP phosphodiesterase and lipid mobilization in rat adipocytes. Biochem. Pharmacol. 1992, 44, 1307-1315. [CrossRef]

15. Dallas, C.; Gerbi, A.; Tenca, G.; Juchaux, F.; Bernard, F.-X. Lipolytic effect of a polyphenolic citrus dry extract of red orange, grapefruit, orange (SINETROL) in human body fat adipocytes. Mechanism of action by inhibition of cAMP-phosphodiesterase (PDE). Phytomedicine 2008, 15, 783-792. [CrossRef] [PubMed]

16. Dell'Agli, M.; Galli, G.V.; Vrhovsek, U.; Mattivi, F.; Bosisio, E. In vitro inhibition of human cGMP-specific phosphodiesterase-5 by polyphenols from red grapes. J. Agric. Food Chem. 2005, 53, 1960-1965. [CrossRef] [PubMed]

17. Ziyyat, A.; Legssyer, A.; Mekhfi, H.; Dassouli, A.; Serhrouchni, M.; Benjelloun, W. Phytotherapy of hypertension and diabetes in oriental Morocco. J. Ethnopharmacol. 1997, 58, 45-54. [CrossRef] 
18. Ziyyat, A.; Mekhfi, H.; Bnouham, M.; Tahri, A.; Legssyer, A.; Hoerter, J.; Fischmeister, R. Arbutus unedo induces endothelium-dependent relaxation of the isolated rat aorta. Phytother. Res. 2002, 16, 572-575. [CrossRef] [PubMed]

19. Afkir, S.; Nguelefack, T.B.; Aziz, M.; Zoheir, J.; Cuisinaud, G.; Bnouham, M.; Mekhfi, H.; Legssyer, A.; Lahlou, S.; Ziyyat, A. Arbutus unedo prevents cardiovascular and morphological alterations in L-NAME-induced hypertensive rats Part I: Cardiovascular and renal hemodynamic effects of Arbutus unedo in L-NAME-induced hypertensive rats. J. Ethnopharmacol. 2008, 116, 288-295. [CrossRef] [PubMed]

20. El Haouari, M.; López, J.J.; Mekhfi, H.; Rosado, J.A.; Salido, G.M. Antiaggregant effects of Arbutus unedo extracts in human platelets. J. Ethnopharmacol. 2007, 113, 325-331. [CrossRef] [PubMed]

21. Mekhfi, H.; ElHaouari, M.; Bnouham, M.; Aziz, M.; Ziyyat, A.; Legssyer, A. Effects of extracts and tannins from Arbutus unedo leaves on rat platelet aggregation. Phytother. Res. 2006, 20, 135-139. [CrossRef] [PubMed]

22. Pallauf, K.; Rivas-Gonzalo, J.; Del Castillo, M.; Cano, M.; de Pascual-Teresa, S. Characterization of the antioxidant composition of strawberry tree (Arbutus unedo L.) fruits. J. Food Compost. Anal. 2008, 21, 273-281. [CrossRef]

23. Pawlowska, A.M.; De Leo, M.; Braca, A. Phenolics of Arbutus unedo L.(Ericaceae) fruits: Identification of anthocyanins and gallic acid derivatives. J. Agric. Food Chem. 2006, 54, 10234-10238. [CrossRef] [PubMed]

24. Pimpão, R.C.; Dew, T.; Oliveira, P.B.; Williamson, G.; Ferreira, R.B.; Santos, C.N. Analysis of phenolic compounds in Portuguese wild and commercial berries after multienzyme hydrolysis. J. Agric. Food Chem. 2013, 61, 4053-4062. [CrossRef] [PubMed]

25. Pavlović, R.; Lakušićć, B.; Došlov-Kokoruš, Z.; Kovačević, N. Arbutin content and antioxidant activity of some Ericaceae species. Die Pharm. Int. J. Pharm. Sci. 2009, 64, 656-659. [CrossRef]

26. Astill, C.; Birch, M.R.; Dacombe, C.; Humphrey, P.G.; Martin, P.T. Factors affecting the caffeine and polyphenol contents of black and green tea infusions. J. Agric. Food Chem. 2001, 49, 5340-5347. [CrossRef] [PubMed]

27. Chen, Z.-Y.; Zhu, Q.Y.; Tsang, D.; Huang, Y. Degradation of green tea catechins in tea drinks. J. Agric. Food Chem. 2001, 49, 477-482. [CrossRef] [PubMed]

28. Perva-Uzunalić, A.; Škerget, M.; Knez, Ž.; Weinreich, B.; Otto, F.; Grüner, S. Extraction of active ingredients from green tea (Camellia sinensis): Extraction efficiency of major catechins and caffeine. Food Chem. 2006, 96, 597-605. [CrossRef]

29. Sharangi, A. Medicinal and therapeutic potentialities of tea (Camellia sinensis L.) -A review. Food Res. Int. 2009, 42, 529-535. [CrossRef]

30. Lin, J.-K.; Lin, C.-L.; Liang, Y.-C.; Lin-Shiau, S.-Y.; Juan, I.-M. Survey of catechins, gallic acid, and methylxanthines in green, oolong, pu-erh, and black teas. J. Agric. Food Chem. 1998, 46, 3635-3642. [CrossRef]

31. Goto, T.; Yoshida, Y.; Kiso, M.; Nagashima, H. Simultaneous analysis of individual catechins and caffeine in green tea. J. Chromatogr. A 1996, 749, 295-299. [CrossRef]

32. Bonoli, M.; Pelillo, M.; Toschi, T.G.; Lercker, G. Analysis of green tea catechins: Comparative study between HPLC and HPCE. Food Chem. 2003, 81, 631-638. [CrossRef]

33. Zuo, Y.; Chen, H.; Deng, Y. Simultaneous determination of catechins, caffeine and gallic acids in green, Oolong, black and pu-erh teas using HPLC with a photodiode array detector. Talanta 2002, 57, 307-316. [CrossRef]

34. Imai, K.; Nakachi, K. Cross sectional study of effects of drinking green tea on cardiovascular and liver diseases. BMJ 1995, 310, 693-696. [CrossRef] [PubMed]

35. Kuriyama, S.; Shimazu, T.; Ohmori, K.; Kikuchi, N.; Nakaya, N.; Nishino, Y.; Tsubono, Y.; Tsuji, I. Green tea consumption and mortality due to cardiovascular disease, cancer, and all causes in Japan: The Ohsaki study. JAMA 2006, 296, 1255-1265. [CrossRef] [PubMed]

36. Kang, W.-S.; Lim, I.-H.; Yuk, D.-Y.; Chung, K.-H.; Park, J.-B.; Yoo, H.-S.; Yun, Y.-P. Antithrombotic activities of green tea catechins and (-)-epigallocatechin gallate. Thromb. Res. 1999, 96, 229-237. [CrossRef]

37. Ok, W.-J.; Cho, H.-J.; Kim, H.-H.; Lee, D.-H.; Kang, H.-Y.; Kwon, H.-W.; Rhee, M.H.; Kim, M.; Park, H.-J. Epigallocatechin-3-gallate has an anti-platelet effect in a cyclic AMP-dependent manner. J. Atheroscler. Thromb. 2012, 19, 337-348. [CrossRef] [PubMed]

38. Son, D.-J.; Cho, M.-R.; Jin, Y.-R.; Kim, S.-Y.; Park, Y.-H.; Lee, S.-H.; Akiba, S.; Sato, T.; Yun, Y.-P. Antiplatelet effect of green tea catechins: A possible mechanism through arachidonic acid pathway. Prostaglandins Leukot. Essent. Fatty Acids 2004, 71, 25-31. [CrossRef] [PubMed] 
39. Bundy, R.; Walker, A.F.; Middleton, R.W.; Wallis, C.; Simpson, H.C. Artichoke leaf extract (Cynara scolymus) reduces plasma cholesterol in otherwise healthy hypercholesterolemic adults: A randomized, double blind placebo controlled trial. Phytomedicine 2008, 15, 668-675. [CrossRef] [PubMed]

40. Englisch, W.; Beckers, C.; Unkauf, M.; Ruepp, M.; Zinserling, V. Efficacy of Artichoke dry extract in patients with hyperlipoproteinemia. Arzneim. Forsch. 2000, 50, 260-265. [CrossRef] [PubMed]

41. Li, H.; Xia, N.; Brausch, I.; Yao, Y.; Förstermann, U. Flavonoids from artichoke (Cynara scolymus L.) up-regulate endothelial-type nitric-oxide synthase gene expression in human endothelial cells. J. Pharmacol. Exp. Ther. 2004, 310, 926-932. [CrossRef] [PubMed]

42. Zapolska-Downar, D.; Zapolski-Downar, A.; Naruszewicz, M.; Siennicka, A.; Krasnodębska, B.; Kołodziej, B. Protective properties of artichoke (Cynara scolymus) against oxidative stress induced in cultured endothelial cells and monocytes. Life Sci. 2002, 71, 2897-2908. [CrossRef]

43. Gebhardt, R. Antioxidative and protective properties of extracts from leaves of the artichoke (Cynara scolymus L.) against hydroperoxide-induced oxidative stress in cultured rat hepatocytes. Toxicol. Appl. Pharmacol. 1997, 144, 279-286. [CrossRef] [PubMed]

44. Lombardo, S.; Pandino, G.; Mauromicale, G.; Knödler, M.; Carle, R.; Schieber, A. Influence of genotype, harvest time and plant part on polyphenolic composition of globe artichoke [Cynara cardunculus L. var. scolymus (L.) Fiori]. Food Chem. 2010, 119, 1175-1181. [CrossRef]

45. Pandino, G.; Lombardo, S.; Mauromicale, G.; Williamson, G. Profile of polyphenols and phenolic acids in bracts and receptacles of globe artichoke (Cynara cardunculus var. scolymus) germplasm. J. Food Compost. Anal. 2011, 24, 148-153. [CrossRef]

46. Schütz, K.; Kammerer, D.; Carle, R.; Schieber, A. Identification and quantification of caffeoylquinic acids and

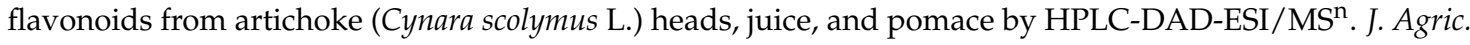
Food Chem. 2004, 52, 4090-4096. [CrossRef]

47. Wang, M.; Simon, J.E.; Aviles, I.F.; He, K.; Zheng, Q.-Y.; Tadmor, Y. Analysis of antioxidative phenolic compounds in artichoke (Cynara scolymus L.). J. Agric. Food Chem. 2003, 51, 601-608. [CrossRef] [PubMed]

48. Samek, Z.; Holub, M.; Drożdż, B.; Iommi, G.; Corbella, A.; Gariboldi, P. Sesquiterpenic lactones of the Cynara scolymus L. species. Tetrahedron Lett. 1971, 12, 4775-4778. [CrossRef]

49. Jiang, H.; Sólyom, A.M.; Timmermann, B.N.; Gang, D.R. Characterization of gingerol-related compounds in ginger rhizome (Zingiber officinale Rosc.) by high-performance liquid chromatography/electrospray ionization mass spectrometry. Rapid Commun. Mass Spectrom. 2005, 19, 2957-2964. [CrossRef] [PubMed]

50. Wohlmuth, H.; Leach, D.N.; Smith, M.K.; Myers, S.P. Gingerol content of diploid and tetraploid clones of ginger (Zingiber officinale Roscoe). J. Agric. Food Chem. 2005, 53, 5772-5778. [CrossRef] [PubMed]

51. Abdel-Aziz, H.; Windeck, T.; Ploch, M.; Verspohl, E.J. Mode of action of gingerols and shogaols on 5-HT 3 receptors: Binding studies, cation uptake by the receptor channel and contraction of isolated guinea-pig ileum. Eur. J. Pharmacol. 2006, 530, 136-143. [CrossRef] [PubMed]

52. Heimes, K.; Feistel, B.; Verspohl, E.J. Impact of the 5-HT 3 receptor channel system for insulin secretion and interaction of ginger extracts. Eur. J. Pharmacol. 2009, 624, 58-65. [CrossRef] [PubMed]

53. Qian, Q.-H.; Yue, W.; Chen, W.-H.; Yang, Z.-H.; Liu, Z.-T.; Wang, Y.-X. Effect of gingerol on substance P and $\mathrm{NK}_{1}$ receptor expression in a vomiting model of mink. Chin. Med. J. 2010, 123, 478-484. [CrossRef] [PubMed]

54. Abdel-Aziz, H.; Nahrstedt, A.; Petereit, F.; Windeck, T.; Ploch, M.; Verspohl, E. 5-HT 3 receptor blocking activity of arylalkanes isolated from the rhizome of Zingiber officinale. Planta Med. 2005, 71, 609-616. [CrossRef] [PubMed]

55. Riyazi, A.; Hensel, A.; Bauer, K.; Geissler, N.; Schaaf, S.; Verspohl, E. The effect of the volatile oil from ginger rhizomes (Zingiber officinale), its fractions and isolated compounds on the $5-\mathrm{HT}_{3}$ receptor complex and the serotoninergic system of the rat ileum. Planta Med. 2007, 73, 355-362. [CrossRef] [PubMed]

56. Tjendraputra, E.; Tran, V.H.; Liu-Brennan, D.; Roufogalis, B.D.; Duke, C.C. Effect of ginger constituents and synthetic analogues on cyclooxygenase-2 enzyme in intact cells. Bioorg. Chem. 2001, 29, 156-163. [CrossRef] [PubMed]

57. Yusof, Y.; Ahmad, N.; Das, S.; Sulaiman, S.; Murad, N. Chemopreventive efficacy of ginger (Zingiber officinale) in ethionine induced rat hepatocarcinogenesis. Afr. J. Tradit. Complement. Altern. Med. 2009, 6, 87-93. [CrossRef] 
58. Adhikari, S.; Priyadarsini, K.I.; Mukherjee, T. Physico-chemical studies on the evaluation of the antioxidant activity of herbal extracts and active principles of some Indian medicinal plants. J. Clin. Biochem. Nutr. 2007, 40, 174-183. [CrossRef] [PubMed]

59. Patro, B.; Adhikari, S.; Chintalwar, G.; Chattopadhyay, S.; Mukherjee, T. The radioprotection and antioxidant properties of dehydrogingerdione. Res. Chem. Intermed. 2005, 31, 667-678. [CrossRef]

60. Thein, K.; Myint, W.; Myint, M.M.; Aung, S.P.; Khin, M.; Than, A.; Bwin, M. Preliminary screening of medicinal plants for biological activity based on inhibition of cyclic AMP phosphodiesterase. Pharm. Biol. 1995, 33, 330-333. [CrossRef]

61. Ghayur, M.N.; Gilani, A.H.; Afridi, M.B.; Houghton, P.J. Cardiovascular effects of ginger aqueous extract and its phenolic constituents are mediated through multiple pathways. Vasc. Pharmacol. 2005, 43, $234-241$. [CrossRef] [PubMed]

62. Kobayashi, M.; Shoji, N.; Ohizumi, Y. Gingerol, a novel cardiotonic agent, activates the Ca ${ }^{2+}$-pumping ATPase in skeletal and cardiac sarcoplasmic reticulum. BBA Biomembr. 1987, 903, 96-102. [CrossRef]

63. Chang, T.-T.; Chen, K.-C.; Chang, K.-W.; Chen, H.-Y.; Tsai, F.-J.; Sun, M.-F.; Chen, C.Y.-C. In silico pharmacology suggests ginger extracts may reduce stroke risks. Mol. Biosyst. 2011, 7, 2702-2710. [CrossRef] [PubMed]

64. Erk, T.; Hauser, J.; Williamson, G.; Renouf, M.; Steiling, H.; Dionisi, F.; Richling, E. Structure- and dose-absorption relationships of coffee polyphenols. Biofactors 2014, 40, 103-112. [CrossRef] [PubMed]

65. Cui, T.; Nakamura, K.; Ma, L.; Li, J.-Z.; Kayahara, H. Analyses of arbutin and chlorogenic acid, the major phenolic constituents in oriental pear. J. Agric. Food Chem. 2005, 53, 3882-3887. [CrossRef] [PubMed]

66. He, X.-G.; Bernart, M.W.; Lian, L.-Z.; Lin, L.-Z. High-performance liquid chromatography-electrospray mass spectrometric analysis of pungent constituents of ginger. J. Chromatogr. A 1998, 796, 327-334. [CrossRef]

67. Marko, D.; Pahlke, G.; Merz, K.-H.; Eisenbrand, G. Cyclic 3' ,5'-Nucleotide Phosphodiesterases: Potential Targets for Anticancer Therapy. Chem. Res. Toxicol. 2000, 13, 944-948. [CrossRef] [PubMed]

68. Montoya, G.A. In Vitro and In Vivo Biofunctional Effects of Selected Coffee Compounds, Extracts and Brews on Key Elements of Adenosine Receptor-Mediated Signaling Pathways and on Cellular Heme Oxygenase. Ph.D. Thesis, University of Kaiserslautern, Kaiserslautern, Germany, 25 April 2012.

69. Li, Z.; Pan, Q.; Cui, X.; Duan, C. Optimization on anthocyanins extraction from wine grape skins using orthogonal test design. Food Sci. Biotechnol. 2010, 19, 1047-1053. [CrossRef]

70. Ruiz-Rodríguez, B.M.; Sánchez-Moreno, C.; Ancos, B.D.; Cortes, M.; Fernández Ruíz, V.; Cámara, M.; Tardío, J. Wild Arbutus unedo L. and Rubus ulmifolius Schott fruits are underutilized sources of valuable bioactive compounds with antioxidant capacity. Fruits 2014, 69, 435-448. [CrossRef]

71. Oliveira, I.; Baptista, P.; Malheiro, R.; Casal, S.; Bento, A.; Pereira, J.A. Influence of strawberry tree (Arbutus unedo L.) fruit ripening stage on chemical composition and antioxidant activity. Food Res. Int. 2011, 44, 1401-1407. [CrossRef]

72. Blaut, M.; Braune, A.; Wunderlich, S.; Sauer, P.; Schneider, H.; Glatt, H. Mutagenicity of arbutin in mammalian cells after activation by human intestinal bacteria. Food Chem. Toxicol. 2006, 44, 1940-1947. [CrossRef] [PubMed]

73. Chang, C.-L.; Wu, R.-T. Quantification of (+)-catechin and (-)-epicatechin in coconut water by LC-MS. Food Chem. 2011, 126, 710-717. [CrossRef]

74. Li, D.-Q.; Qian, Z.-M.; Li, S.-P. Inhibition of three selected beverage extracts on $\alpha$-glucosidase and rapid identification of their active compounds using HPLC-DAD-MS/MS and biochemical detection. J. Agric. Food Chem. 2010, 58, 6608-6613. [CrossRef] [PubMed]

75. Zick, S.M.; Djuric, Z.; Ruffin, M.T.; Litzinger, A.J.; Normolle, D.P.; Alrawi, S.; Feng, M.R.; Brenner, D.E. Pharmacokinetics of 6-gingerol, 8-gingerol, 10-gingerol, and 6-shogaol and conjugate metabolites in healthy human subjects. Cancer Epidemiol. Biomark. Prev. 2008, 17, 1930-1936. [CrossRef] [PubMed]

(C) 2017 by the authors. Licensee MDPI, Basel, Switzerland. This article is an open access article distributed under the terms and conditions of the Creative Commons Attribution (CC BY) license (http:/ / creativecommons.org/licenses/by/4.0/). 